\title{
Audiência pública e advocacia EM SAÚDE: O CASO DA ADI No $3.510-0$
}

PUBLIC AUDIENCE AND HEALTH ADVOCACY: THE CASE OF ADI N³.510-0

\author{
Nathália Molleis Miziara*
}

\section{RESUMO}

Análise atenta sobre o julgamento da Ação Direta de Inconstitucionalidade (ADI) $\mathrm{n}^{\circ}$ 3.510-0 permite observar que as audiências públicas podem ser utilizadas de forma eficaz na realização de advocacia em saúde, junto ao Poder Judiciário, mais especificamente, no âmbito do Supremo Tribunal Federal. Pretendeu-se avaliar como as participações em audiências públicas podem representar sucesso de advocacia em saúde, tendo como exemplo paradigmático o caso da $\mathrm{ADI} \mathrm{n}^{\circ} 3.510-0$, referente à pesquisa com células-tronco embrionárias. O objetivo primordial foi averiguar em que medida os argumentos dos especialistas participantes da audiência pública influenciaram os ministros do Supremo Tribunal Federal na elaboração dos votos favoráveis à Lei de Biossegurança. A metodologia utilizada consistiu na identificação de citações e referências expressas a trechos da audiência pública na fundamentação dos votos dos ministros. Os resultados obtidos apontaram que metade dos ministros que votaram favoravelmente à pesquisa com células-tronco embrionárias utilizaram argumentos explicitados na audiência pública na fundamentação de seus votos, tendo sido influenciados diretamente pelo discurso dos palestrantes defensores da Lei de Biossegurança.

\section{Palavras-chave:}

ADI 3.510-0; Advocacia em Saúde; Audiência Pública; Poder Judiciário. (*) Mestranda em Direito Econômico, Faculdade de Direito, Universidade de São Paulo. São Paulo-SP
/ Brasil. E-mail: nathalia.miziara@usp.br.

Texto recebido em 03.09.11. Revisado em 06.03.12. Aprovado em 06.03.12. 


\begin{abstract}
Careful analysis of the case of the Brazilian Direct Action of Unconstitutionality no. 3,510-0 (ADI no. 3,510-0) allows to observe that public hearings can be used as an effective form to execute health advocacy before the Judiciary Power. The present article intends to evaluate the reasons why participation in public hearings can represent a success of health advocacy by having as an example the paradigmatic case of ADI no. 3,510-0, regarding research with embryonic cells. The main objective was to investigate to what extent the arguments delivered by the specialists who attended the public hearing influenced ministers of the Brazilian constitutional court in the preparation of the votes in favor of embryonic stem cell research. The methodology used consisted in the identification of citations and explicit references to sections of the public hearing in the grounds of ministers' votes. The results obtained indicated that half of the ministers who voted in favor of embryonic stem cell research used arguments explicitly delivered in the public hearing in order to base their decision, having been, therefore, directly influenced by the speech of participants who defended the biosafety law.
\end{abstract}

\title{
Keywords:
}

Brazilian Direct Action of Unconstitutionality no. 3,510-0; Health Advocacy; Judiciary Power; Public Hearing.

\section{INTRODUÇÃO}

Em 31 de maio de 2005, pouco tempo depois da aprovação da Lei de Biossegurança $^{(1)}$ pelo Congresso Nacional, foi ajuizada a Ação Direta de Inconstitucionalidade $(\mathrm{ADI}) \mathrm{n}^{\circ} 3.510-0^{(2)}$, impugnando o Art. $5^{\circ}$ e parágrafos dessa lei. O objetivo dessa ação era proibir a pesquisa científica em células-tronco embrionárias, principalmente, sob o argumento de que isso representaria violação do direito constitucional à vida. Entretanto, tal ação foi julgada improcedente pelo

(1) BRASIL. Lei $n^{\circ} 11.105$, de 24 de março de 2005, "Regulamenta os incisos II, IV e V do $\S 10$ do art. 225 da Constituição Federal, estabelece normas de segurança e mecanismos de fiscalização de atividades que envolvam organismos geneticamente modificados - OGM e seus derivados, cria o Conselho Nacional de Biossegurança - CNBS, reestrutura a Comissão Técnica Nacional de Biossegurança - CTNBio, dispõe sobre a Política Nacional de Biossegurança - PNB, revoga a Lei no 8.974, de 5 de janeiro de 1995, e a Medida Provisória no 2.191-9, de 23 de agosto de 2001, e os arts. 5o, 6o, 7o, 8o, 9o, 10 e 16 da Lei no 10.814, de 15 de dezembro de 2003, e dá outras providências". Disponível em: <http://www.planalto.gov.br/ccivil_03/_Ato2004-2006/2005/Lei/L11105.htm>. Acesso em: 2 ago. 2012.

(2) SUPREMO TRIBUNAL FEDERAL. Ação Direta de Inconstitucionalidade no. 3.510-0. Informativo STF, Brasília-DF, n. 508, 26-30 maio 2008. Disponível em: <http://www.stf.jus.br/arquivo/informativo/ documento/informativo508.htm>. Acesso em: 2 ago. 2012. 
Supremo Tribunal Federal (STF), em razão do que pode ser considerado o sucesso de advocacia em saúde que representou a audiência pública nesse caso.

Nos últimos tempos, o Supremo Tribunal Federal tem recorrido à realização de audiências públicas preparatórias em julgamentos de ações cuja temática envolva casos relevantes à saúde pública. Na última década, esse tribunal efetuou cinco audiências públicas, nos termos da lei processual, sendo três delas relativas a questões sanitárias. ${ }^{(3)}$ Foi, contudo, na $A D I n^{\circ} 3.510-0$ que o STF utilizou pela primeira vez o referido instituto processual. O propósito foi auxiliar no julgamento de matéria específica, cuja temática era ignorada pela maioria dos membros do tribunal.

A escolha da ADI n 3.510-0 para a realização de estudo de caso a fim de demonstrar a possibilidade de se realizar advocacia em saúde, junto ao Poder Judiciário, mediante a participação em audiências públicas, se justifica por três razões. Em primeiro lugar, foi nesse julgamento que o Supremo Tribunal Federal utilizou, pela primeira vez, o instituto da audiência pública, nos termos da lei processual. Em segundo lugar, foi também a primeira vez que a audiência pública foi empregada como instrumento para a prática de advocacia em saúde no âmbito do STF. Por último, considerando que o julgamento final do tribunal determinou a improcedência da ADI $n^{\circ} 3.510-0$, é possível afirmar que o caso representa um sucesso de advocacia em saúde.

A metodologia aplicada consistiu em aferir quais argumentos aduzidos pelos participantes da audiência pública e favoráveis às pesquisas com células embrionárias foram acolhidos pelos ministros do STF, como base de fundamentação de seus votos pela improcedência da ação. Para tanto, foram identificadas nos votos citações e transcrições expressas de trechos da audiência pública relativos ao discurso dos participantes defensores da pesquisa com células embrionárias. A verificação dessas referências permitiu constatar a existência de uma relação positiva entre a exposição daqueles participantes da audiência pública favoráveis a estudos científicos com células-tronco embrionárias e a argumentação dos membros do Supremo Tribunal Federal no caso em questão.

Tais argumentos foram realizados majoritariamente por cientistas engajados e defensores da causa. O conteúdo argumentativo variou entre aspectos científicos, éticos e morais e apelos emocionais ${ }^{(4)}$, evidenciando a intenção persuasiva dos participantes. Desse modo, é possível afirmar que, no caso da audiência pública da ADI n³.510-0, foi realizada verdadeira advocacia em saúde, em prol das pesquisas com células-tronco embrionárias.

(3) No que concerne a questões sanitárias analisadas pelo STF, além da audiência pública relativa à $\mathrm{ADI} \mathrm{n}^{\circ} 3.510-0$, foram realizadas audiências públicas na ADPF $\mathrm{n}^{\circ} 54$ (aborto do feto anencéfalo), no julgamento dos agravos regimentais nas suspensões de liminares $n^{\circ} 47$ e $n^{\circ} 64$ e suspensões de tutela antecipada $n^{\circ} 36, n^{\circ} 185, n^{\circ} 211$ e $n^{\circ} 278$ (SUS).

(4) Na audiência pública, Mayana Zatz narra o caso de uma criança com paralisia que pede para que lhe seja acoplado uma engenhoca, similar a de uma boneca, para que possa andar assim como o brinquedo. 
As informações prestadas pelos participantes defensores da Lei de Biossegurança influenciaram diretamente o posicionamento dos ministros do Supremo Tribunal Federal, tendo sido utilizadas, inúmeras vezes, conforme este artigo pretende demonstrar, na fundamentação dos votos. O exercício da advocacia em saúde em prol das pesquisas com células-tronco embrionárias foi, nesse caso, portanto, bem-sucedido e deve servir de exemplo para outras situações que envolvam a defesa de interesses sanitários.

Antes de adentrar no tema propriamente dito, por sua vez, é necessário realizar algumas considerações acerca do que se entende por advocacia em saúde e, posteriormente, estudar a utilização de audiências públicas pelo Supremo Tribunal Federal.

\section{ADVOCACIA EM SAÚDE}

\section{NOÇÃO DE ADVOCACIA}

O termo advocacia remete à palavra de raiz inglesa advocacye, de modo geral, diz respeito a:

um processo de reivindicação de direitos ou a atividade de um grupo, visando influir na definição ou na implementação de uma política pública. A suposição básica é que as pessoas têm direitos fundamentais que são exigiveis por meio de procedimentos legislativos, administrativos ou judiciais. ${ }^{(5)}$

A advocacia refere-se, basicamente, às seguintes ações: alteração de leis, monitoramento do Legislativo, elaboração e implementação de orçamentos, bem como acompanhamento de processos administrativos. ${ }^{(6)}$

É importante diferenciar a referida noção de advocacia (em sentido amplo) da ideia de advocacia que deriva da atividade praticada exclusivamente pelos bacharéis em direito (aquela em sentido estrito). A principal distinção entre as duas noções diz respeito ao envolvimento político na causa, necessário à advocacia em sentido amplo(7). Não obstante, existem outras diferenças que merecem destaque, a saber: (1) a advocacia em sentido amplo diz respeito a serviços legais inovadores de interesse coletivo, em que não há uma relação hierarquizada entre cliente e advogado e não precisa ser necessariamente desenvolvida por profissionais da área jurídica, enquanto (2) a advocacia em sentido estrito refere-se ao atendimento individualizado em serviços legais

(5) CANEL, Regina Célia; CASTRO, Cláudio Gastão Junqueira de. A advocacia em saúde como uma estratégia para a promoção da saúde. Revista de Direito Sanitário, São Paulo, v. 9, n. 1, p. 74-85, mar./jun. 2008. p.78

(6) Id. Ibid., p. 79.

(7) DALLARI, Sueli Gandolfi et al. Advocacia em saúde no Brasil contemporâneo. Revista Saúde Pública, São Paulo, v. 30, n. 6, 1996. p. 597. 
tradicionais e pressupõe o exercício por um bacharel em direito ${ }^{(8)}$.

A atividade designada por advocacia em sentido amplo pode ser exercida em benefício dos mais variados direitos. Quando o interesse a ser defendido está relacionado com o direito à saúde, o processo de advocacia passa a ser especializado, sendo designado como advocacia em saúde. ${ }^{(9)}$

\section{ADVOCACIA EM SAÚDE E CORREÇÃO DE FALHAS INSTITUCIONAIS}

No Brasil, muitos dos problemas relacionados à saúde não concernem ao reconhecimento e à positivação desse direito, mas a sua eficácia. Segundo Tércio Sampaio Ferraz Jr., a eficácia é uma qualidade da norma que se refere à possibilidade de produção concreta de efeitos, porque estão presentes as condições fáticas exigíveis para sua observância, espontânea ou imposta, ou para a satisfação de objetivos visados, ou porque estão presentes as condições técnico-normativas exigíveis para sua aplicação. ${ }^{(10)}$

O direito à saúde, assim como os demais direitos fundamentais, só importa na medida em que pode ser concretizado, sendo insuficiente a mera positivação. Este direito está presente no ordenamento jurídico, mas seu exercício é comumente limitado por falhas institucionais que resultam em problemas causadores de danos individuais e coletivos.

Diante desse quadro, a advocacia em saúde é utilizada para reivindicar a implementação do direito e para exercer influência sobre políticas públicas referentes a sua realização. ${ }^{(11)}$ Assim, é no âmbito da eficácia normativa que a advocacia em saúde atua, buscando corrigir as omissões institucionais na promoção do direito à saúde.

\section{AUDIÊNCIAS PÚBLICAS}

A possibilidade de realização de audiências públicas com o propósito de esclarecer determinada matéria e requerer informações adicionais foi

(8) DALLARI, Sueli Gandolfi et al. op. cit., p. 597.

(9) CANEL, Regina Célia; CASTRO, Cláudio Gastão Junqueira de. op. cit., p. 78.

(10) FERRAZ JR., Tércio Sampaio, Introdução ao estudo do direito: técnica, decisão e dominação. 4. ed. São Paulo: Atlas, 2003. p. 203.

(11) ZIONI, Fabíola. A advocacia em saúde e sua contribuição à democracia. Revista de Direito Sanitário, São Paulo, v. 9, n. 1, maio/jun. 2008. p. 72. 
estabelecida pela Lei $n^{\circ}$ 9.868. ${ }^{(12)}$ Não há previsão no Regimento Interno do Supremo Tribunal Federal sobre a realização de audiência pública, o que, por sua vez, não impossibilita esse órgão de utilizá-la. O objetivo da audiência pública é ouvir depoimentos de pessoas com experiência e autoridade nas matérias em que se entenda necessário esclarecimento. ${ }^{(13)}$

Contudo, apenas em 20 de abril de 2007, foi realizada a primeira audiência pública pelo Supremo Tribunal Federal. A realização dessa audiência foi pleiteada pelo Procurador Geral da República na petição inicial da ADI $n^{\circ}$ 3.510-0. O relator da ação, o ministro Ayres Brito, acolheu o pedido do autor com o objetivo de esclarecer questionamentos referentes à tutela do direito à vida, supostamente ameaçado pela permissão de pesquisa científica em células-tronco embrionárias, nos termos da Lei de Biossegurança. De fato, o julgamento de matéria tão específica como a questão da pesquisa em células-tronco embrionárias precisava de mais esclarecimentos. Segundo o ministro Ayres Britto, a finalidade da audiência seria possibilitar "maior participação da sociedade civil no enfrentamento da controvérsia constitucional", legitimando ainda mais a decisão tomada pelo Plenário. ${ }^{(14)}$

Desde então, o Supremo Tribunal Federal recorreu outras vezes à realização de audiências públicas (ADPF $n^{\circ} 54$, ADPF $n^{\circ} 101$; julgamento dos agravos regimentais nas suspensões de liminares $n^{\circ} 47$ e $n^{\circ} 64$, suspensões de tutela antecipada $n^{\circ} 36, n^{\circ} 185, n^{\circ} 211, n^{\circ} 278$, e suspensões de segurança $n^{\circ} 2.361, n^{\circ} 2.944, n^{\circ} 3.345, n^{\circ} 3.355$; e audiência pública sobre políticas de ação afirmativa de reserva de vagas no ensino superior).

\section{APRESENTAÇÃO DO CASO}

O caso em análise concerne ao exercício de advocacia em saúde, por meio da participação em audiência pública de membros da sociedade civil, diretamente interessados na realização de pesquisa com células-tronco embrionárias. O

(12) Art. $9^{\circ}, \S 1^{\circ}$ - "[e]m caso de necessidade de esclarecimento de matéria ou circunstância de fato ou de notória insuficiência das informações existentes nos autos, poderá o relator requisitar informações adicionais, designar perito ou comissão de peritos para que emita parecer sobre a questão, ou fixar data para, em audiência pública, ouvir depoimentos de pessoas com experiência e autoridade na matéria". BRASIL. Lei no. 9.869, de 10 de novembro de 1999, "Dispõe sobre o processo e julgamento da ação direta de inconstitucionalidade e da ação declaratória de constitucionalidade perante o Supremo Tribunal Federal". Disponível em: <http://www.planalto.gov.br/ccivil_03/Leis/L9868.htm>. Acesso em: 2 ago. 2012.

(13) BELLEM, Rafael Scavone de Lima. A audiência pública realizada na ADI 3510: a organização e o aproveitamento da primeira audiência pública da história do Supremo Tribunal Federal. Monografia (Conclusão de Curso) - Sociedade Brasileira de Direito Público, SBDP, Escola de Formação, São Paulo, 2008. p. 16.

(14) ADI n³.510-0. 
propósito dessas pessoas, majoritariamente médicos e cientistas envolvidos em pesquisas científicas com células embrionárias, apoiados por outros defensores da causa, é descobrir novas terapias para doenças incuráveis, tais como doenças degenerativas, neuromusculares, dentre outras.

AADI n 3.510-0 foi proposta pelo Procurador Geral da República contra o Art. $5^{\circ}$ e parágrafos da Lei $n^{\circ} 11.105$, sob o argumento de que teriam sido violados o direito à vida (Art. $5^{\circ(15)}$, caput, da Constituição Federal) e o direito à dignidade da pessoa humana (Art. $1^{\circ}$, III, da Constituição Federal). A tese central sustentada pelo Procurador Geral da República era de que a vida humana acontece a partir da fecundação e, por isso, desde esse momento, deveria ser preservada. Essa situação não ocorreria nas pesquisas com embriões humanos, uma vez que, para utilizar essas células em pesquisa, o embrião é necessariamente destruído. No mais, o Procurador Geral da República formulou pedido para realização de audiência pública para elucidar questões relativas ao tema, o qual foi aceito pelo ministro relator Carlos Ayres Britto, conforme mencionado anteriormente.

Participaram do referido processo como interessados, na qualidade de amici curiae: Conectas Direitos Humanos, Centro de Direitos Humanos (CDH), Movimento em Prol da Vida (Movitae), Instituto de Bioética, Direitos Humanos e Gênero (ANIS) e Confederação Nacional dos Bispos do Brasil (CNBB). Os amici curiae e o Procurador Geral da República, o Presidente da República e o Congresso Nacional foram responsáveis pela designação dos nomes de especialistas ouvidos na audiência pública.

Como resultado, a ADI $n^{\circ} 3.510-0$ foi julgada improcedente, permitindo a pesquisa em células-tronco embrionárias, nos termos da Lei de Biossegurança. Votaram nesse sentido seis ministros do Supremo Tribunal Federal, destacando-se o voto do ministro relator.

No total, foram ouvidos 22 especialistas na audiência pública. Todos os expositores, salvo a antropóloga Débora Diniz, tinham formação e atuação na área das ciências médicas e biológicas. Houve divisão em dois blocos de opinião: um contrário à realização das pesquisas com células-tronco embrionárias humanas, nos termos da lei, e outro favorável, cada qual representado por 11 especialistas. ${ }^{(16)}$ Após as apresentações dos dois blocos, os ministros tiveram

(15) Art. $5^{\circ}$ - É permitida, para fins de pesquisa e terapia, a utilização de células-tronco embrionárias obtidas de embriões humanos produzidos por fertilização in vitro e não utilizados no respectivo procedimento, atendidas as seguintes condições: I-sejam embriões inviáveis; ou II-sejam embriões congelados há 3 (três) anos ou mais, na data da publicação desta Lei, ou que, já congelados na data da publicação desta Lei, depois de completarem 3 (três) anos, contados a partir da data de congelamento. §10 Em qualquer caso, é necessário o consentimento dos genitores. § 20 Instituições de pesquisa e serviços de saúde que realizem pesquisa ou terapia com células-tronco embrionárias humanas deverão submeter seus projetos à apreciação e aprovação dos respectivos comitês de ética em pesquisa. § 30 É vedada a comercialização do material biológico a que se refere este artigo e sua prática implica o crime tipificado no art. 15 da Lei no 9.434, de 4 de fevereiro de 1997.

(16) BELLEM, Rafael Scavone de Lima. op. cit., p. 22. 
a oportunidade de elaborar perguntas aos participantes e esclarecer dúvidas técnicas relativas ao tema.

\section{A IMPORTÂNCIA DA PESQUISA EM CÉLULAS- TRONCO EMBRIONÁRIAS PARA A SAÚDE PÚBLICA}

Existem duas espécies de células-tronco cujo potencial terapêutico envolve muitas expectativas, porém ainda está sendo investigado. Essas células podem ser adultas ou embrionárias.

As células-tronco adultas são usadas principalmente no tratamento de doenças do sistema hematopoiético e podem dar origem a todas as células presentes no sangue. Estas células, presentes em vários tecidos adultos do corpo humano, tais como medula óssea, cordão umbilical e placenta, atuam em sua manutenção, repondo células mortas. Contudo, a capacidade de diferenciação desta espécie de célula-tronco é restrita, porquanto se limita ao tecido em que está localizada. Por exemplo, pesquisas científicas indicam que as células-tronco adultas encontradas na medula-óssea são capazes de regenerar apenas o sangue, e as células-tronco presentes no fígado são responsáveis pela reconstituição somente deste órgão. ${ }^{(17)}$

As células-tronco embrionárias, por sua vez, são aquelas encontradas no embrião humano, resultante da fecundação do óvulo pelo espermatozoide, em sua fase inicial. Estas células são originárias da massa celular interna (MCl) do embrião e caracterizam-se pela pluripotência, isto é, quando reinseridas no embrião são capazes de retomar o desenvolvimento celular, produzindo tecidos diferentes, em razão de sua ampla plasticidade. As células-tronco embrionárias têm a habilidade de se diferenciarem nos mais variados tecidos, incluindo o hematopoiético, neuronal, endotelial, cardíaco e muscular. ${ }^{(18)}$

No início da década de 1990, foram realizadas as primeiras pesquisas científicas com células-tronco embrionárias. Tais pesquisas têm particular relevância, em razão do seu potencial terapêutico.

Estudos realizados com animais apontam que as células advindas das linhagens produzidas a partir de células-tronco embrionárias exercem efeito terapêutico sobre várias doenças. O potencial terapêutico destas células foi identificado em doenças como diabetes, Parkinson e paralisia por trauma de medula espinhal, sendo promissoras para tratamentos de inúmeras doenças

(17) PEREIRA, Lygia da Veiga. A importância do uso das células-tronco para a saúde pública. Ciência \& Saúde Coletiva, Rio de Janeiro, v. 13, n. 1, fev. 2008. p.8

(18) Id., loc. cit. 
incuráveis. ${ }^{(19)}$ Por essa razão, existe grande entusiasmo da comunidade científica em relação à pesquisa com essa espécie celular.

\section{ARGUMENTOS FAVORÁVEIS À PESQUISA EM CÉLULAS-TRONCO EMBRIONÁRIAS APRESENTADOS NA AUDIÊNCIA PÚBLICA DA ADI $N^{\circ}$ 3.510 E QUE FORAM ACOLHIDOS PELOS MINISTROS DO STF}

Os cientistas e pesquisadores favoráveis à realização de estudos com células-tronco embrionárias, participantes da audiência pública preparatória do julgamento da $\mathrm{ADI} \mathrm{n}^{\circ}$ 3.510-0, atuaram como advogados dessa causa de relevância sanitária. Suas exposições abrangeram argumentos de ordem técnica, ética, moral e até emocional, favorável aos dispositivos impugnados.

Tanto o bloco expositor favorável à Lei de Biossegurança quanto aquele a ela contrário tiveram autonomia para definir o conteúdo das apresentações. Os principais argumentos apresentados pelos especialistas adeptos da realização de pesquisas com células embrionárias foram acolhidos pelos ministros do STF e puderam ser identificados com base em citações expressas a expositores ou trechos da audiência nos votos proferidos.

A identificação de referências expressas a trechos da audiência ou de citações do posicionamento dos participantes da audiência pública nos votos dos julgadores é o único meio capaz de apontar com absoluto grau de certeza a influência da audiência pública sobre o posicionamento dos ministros do STF. Por esse motivo, este trabalho levou em consideração apenas os argumentos e trechos explicitamente mencionados como oriundos da audiência pública.

Contudo, não se descarta a possibilidade de que os argumentos aduzidos na referida audiência tenham produzido maior influência do que o constatado neste trabalho, indo além do que pôde ser identificado em citações expressas e transcrições de trechos da audiência pública. Ocorre que, por dificuldades de ordem metodológica na apuração do nível de alcance desses argumentos sobre o convencimento de cada um dos ministros, optou-se por selecionar apenas as alegações expressamente referidas nos votos.

Os argumentos acolhidos foram os seguintes:

1. Os embriões utilizados em pesquisa com células-tronco embrionárias são inviáveis

Alguns dos expositores que participaram da audiência pública, com destaque para a médica Patrícia Pranke, procuraram explicitar o significado de "embriões inviáveis", aos quais faz referência a Lei de Biossegurança. Segundo

(19) PEREIRA, Lygia da Veiga. op. cit., p. 8. 
essa lei, as pesquisas em células-tronco embrionárias, bem como sua utilização terapêutica, só podem ser realizadas em embriões inviáveis ou que estejam congelados há mais de três anos. ${ }^{(20)}$ Tais embriões jamais se desenvolveriam em um novo ser, caso fossem implantados em um útero, possuindo, portanto, o destino do descarte.

Sobre a inviabilidade dos embriões explicou Patrícia Pranke, em resposta à pergunta formulada pelo ministro relator ao fim da audiência:

A condição para a inviabilidade é a prevista no Decreto $n^{\circ} 5.591$, que define que embriões inviáveis são aqueles com alterações genéticas comprovadas por diagnóstico pré-implantacional, conforme normas específicas, estabelecidas pelo Ministério da Saúde, que tiveram o seu desenvolvimento interrompido por ausência de clivagem por período superior a 24 horas a partir da fertilização in vitro ou com alterações morfológicas que comprometam o pleno desenvolvimento do embrião. Esse decreto teve ampla participação das sociedades científicas por ocasião da elaboração.(21)

No que concerne à inviabilidade dos embriões utilizados nas pesquisas com células-tronco, o ministro relator Ayres Britto citou o seguinte trecho da audiência pública, referente à exposição da antropóloga Débora Diniz, para explicar a situação de embriões inviáveis:

O diagnóstico de inviabilidade do embrião constitui procedimento médico seguro e atesta a impossibilidade de que o embrião venha a se desenvolver. Mesmo que um embrião inviável venha a ser transferido para um útero, não se desenvolverá em uma futura criança. O único destino possível para eles é o congelamento permanente, o descarte ou a pesquisa científica. ${ }^{(22)}$

\section{A pesquisa em células-tronco embrionárias não consiste em aborto}

A pesquisa com células-tronco embrionárias não implica a realização de aborto, vez que, para que haja aborto, é necessário que exista gravidez, ou seja, que já tenha ocorrido a nidação (fixação do embrião na parede do útero).

Sendo assim, os ministros do STF acolheram a explicação dada pelos especialistas, deixando claro que pesquisa em células-tronco embrionárias não caracteriza aborto, porque não implica a expulsão do embrião ou feto do corpo da mãe. Veja, por exemplo, o seguinte trecho da apresentação da geneticista Mayana Zatz, transcrito pelo ministro Celso de Mello em seu voto:

Pesquisar células embrionárias obtidas de embriões congelados não é aborto. É muito importante que isso fique bem claro. No aborto, temos uma vida no útero que só será interrompida por intervenção humana, enquanto que, no embrião congelado,

(20) Lei $\mathrm{n}^{\circ} 11.105 / 05$, Art. $5^{\circ}$, incisos I e II.

(21) AUDIÊNCIA Pública Células-Tronco. TV Justiça, Brasília-DF, 20 abr. 2007. Disponível em: <http://www.tvjustica.jus.br/videos/audiencia_DV0811_CELULAS_TRONCO_P1.wmv>. Acesso em: 06 mar. 2012.

(22) $\mathrm{ADI} \mathrm{n}^{\circ} 3.510-0$. 
não há vida se não houver intervenção humana. ${ }^{(23)}$

Ainda nesse sentido, dentre os pressupostos que fundamentam o acórdão referente à $A D I n^{\circ} 3.510-0$, consignados no início do acórdão, há o seguinte tópico: "[a]s pesquisas com células-tronco não caracterizam aborto. Matéria estranha a presente ação direta de inconstitucionalidade". A razão fundamental que dá embasamento a essa premissa é a de que a Lei de Biossegurança não cuida de interromper a gravidez humana, considerando que, no caso da fertilização in vitro, ela não existe. ${ }^{(24)}$

3. Irrelevância da discussão sobre o início da vida e dúvida acerca da existência de vida no embrião

Exceto pelo ministro Celso de Mello, todos os ministros que votaram pela improcedência da ADI acolheram a premissa utilizada na audiência pública pelos cientistas defensores da pesquisa em células-tronco embrionárias, qual seja: a irrelevância da discussão sobre o início da vida para a decisão da ADI.

Vale registrar o seguinte trecho do voto proferido pelo ministro relator: “(...) a questão não reside exatamente em se determinar o início da vida do homo sapiens, mas em saber em que aspectos e momentos da vida estão validamente protegidos pelo Direito infraconstitucional e em que medida".(25)

Mais adiante em seu voto, o relator cita um trecho da apresentação da antropóloga Débora Diniz, participante da audiência pública no bloco de especialistas favoráveis à pesquisa com células embrionárias:

Quando a vida humana tem início? O que é vida humana? Essas perguntas contêm um enunciado que remete à regressão infinita: as células humanas no óvulo antes da fecundação, assim como em um óvulo fecundado em um embrião, em um feto, em uma criança ou em um adulto. O ciclo interminável de geração da vida humana envolve células humanas e não humanas, a tal ponto que descrevemos o fenômeno biológico como reprodução, e não simplesmente como produção da vida humana. ${ }^{(26)}$

Em sua exposição, a antropóloga salientou um aspecto importante referente às consequências de assumir a fecundação como início da vida, imputando- Ihe proteções idênticas conferidas aos seres humanos. O ministro relator fez referência a este aspecto em seu voto e transcreveu, mais uma vez, parte da apresentação da antropóloga:

Portanto, considerar o marco da fecundação como suficiente para o reconhecimento do embrião como detentor de todas as proteções jurídicas e éticas disponíveis a alguém, após o nascimento, implica assumir que: primeiro, a fecundação expressaria

(23) ADI no 3.510-0.

(24) Id. Ibid.

(25) Id. Ibid.

(26) Id. Ibid. 
não apenas um marco simbólico na reprodução humana, mas a resumiria heuristicamente; uma tese de cunho essencialmente metafísico. Segundo, haveria uma continuidade entre óvulo fecundado e futura pessoa, mas não entre óvulo não fecundado e outras formas de vida celular humana. Terceiro, na ausência de úteros artificiais, a potencialidade embrionária de vir a se desenvolver intraútero pressuporia o dever de uma mulher à gestação, como forma a garantir a potencialidade da implantação. Quarto, a potencialidade embrionária de vir a se desenvolver intraútero deveria ser garantida por um princípio constitucional do direito à vida. ${ }^{(27)}$

4. Nada impede que o ordenamento jurídico proteja mais certos estágios de vida do que outros

O ministro relator aceitou o argumento trazido pelo bloco de participantes favoráveis à pesquisa em células embrionárias de que o ordenamento jurídico não protege da mesma forma a vida em seus mais variados estágios. Assim, não faz sentido requerer que o embrião tenha a mesma proteção, por exemplo, de um ser humano já constituído biológica e psicologicamente. Dessa forma, o ministro cita em seu voto o seguinte trecho da audiência pública relativo ao discurso da antropóloga Débora Diniz:

Isso não impede que nosso ordenamento jurídico e moral possa reconhecer alguns estágios da biologia humana como passíveis de maior proteção do que outros. É o caso, por exemplo, de um cadáver humano, protegido por nosso ordenamento. No entanto, não há como comparar as proteções jurídicas e éticas oferecidas a uma pessoa adulta com as de um cadáver. ${ }^{(28)}$

5. Importância da pesquisa com células-tronco embrionárias para a cura de doenças incuráveis

Um dos principais motivos para o julgamento pela improcedência da ADI $\mathrm{n}^{\circ} 3.510-0$ foi a possibilidade das pesquisas com células-tronco embrionárias resultarem no desenvolvimento de terapias para doenças graves, hoje incuráveis. Esse argumento foi utilizado na fundamentação dos votos de todos os ministros favoráveis à pesquisa com células-tronco embrionárias.

Os cientistas que participaram da audiência pública enfatizaram a necessidade de pesquisas com células embrionárias, uma vez que tais estudos têm o potencial de culminar em tratamentos e curas para doenças graves que consistem em problemas relevantes para a saúde pública. Nessa linha, o ministro Celso de Mello transcreveu em seu voto o seguinte trecho proferido pela cientista Mayana Zatz na audiência pública:

A terapia com células tronco pode ser considerada como futuro da medicina regenerativa. Entre as áreas mais promissoras, está o tratamento para diabetes,

(27) ADI no 3.510-0.

(28) Id. Ibid. 
doenças neuromusculares, como distrofias musculares progressivas e a doença de Parkinson. Com as células-tronco também se poderá promover a regeneração de tecidos lesionados por causas não hereditárias, como acidentes, ou pelo câncer.(29)

A audiência pública também contribuiu para que os ministros obtivessem informações sobre o número de pessoas atingidas por doenças potencialmente curáveis com terapias baseadas em pesquisa com células embrionárias:(30)

- $\quad$ sete mil doenças genéticas atingem cerca de $3 \%$ das crianças que nascem de pais normais, o que significa mais de cinco milhões de brasileiros;

- $\quad$ nos países de primeiro mundo, essas doenças são responsáveis por mais de $50 \%$ das mortes de crianças no primeiro ano de vida e $1 / 3$ das internações em hospitais pediátricos;

- muitas doenças atingem adultos em função de um componente genético importante, tais como: câncer, mal de Alzheimer, doença de Parkinson, miopia, cardiopatias, doenças hepáticas, dentre outras;

- $\quad$ sequelas neurológicas e musculares de acidentes;

- doenças neuromusculares que afetam um a cada mil indivíduos, isto é, 200 mil brasileiros.

No que diz respeito ao contingente populacional afetado por doenças que podem vir a ser curadas em função dos resultados obtidos em pesquisas com células-tronco embrionárias, o ministro relator Carlos Ayres Britto declarou em seu voto:

Por conseguinte, linhas de pesquisa que não invalidam outras, porque a essas outras vêm a se somar em prol do mesmo objetivo de enfrentamento e cura de patologias e traumatismos que severamente limitam, atormentam, infelicitam, desesperam e não raras vezes degradam a vida de expressivo contingente populacional (ilustrativamente, atrofias espinhais progressivas, distrofias musculares, a esclerose múltipla e a lateral amiotrófica, as neuropatias e as doenças do neurônio motor, além das precedentemente indicadas). Contingente em torno de 5 milhões, somente para contabilizar os "brasileiros que sofrem de algumas doenças genéticas graves", segundo dados levantados pela Revista Época, edição de 29 de abril de 2007, pp.13/17. E quanto aos portadores de diabetes, em nosso país, a projeção do seu número varia de 10 a 15 milhões (...).(31)

Conforme foi possível extrair da audiência pública, é fato que as pesquisas em células-tronco embrionárias parecem ser mais promissoras para a cura de doenças do que as pesquisas realizadas em células-tronco adultas. Isso ocorre em razão da maior plasticidade que as primeiras possuem em comparação com

(29) ADI no 3.510-0.

(30) AUDIÊNCIA Pública Células-Tronco. TV Justiça, Brasília-DF, 20 abr. 2007, cit.

(31) $A D I n^{\circ}$ 3.510-0. 
as segundas. A plasticidade maior das células embrionárias significa que estas células têm o potencial de originar todos os tecidos do nosso corpo, enquanto as células-tronco adultas são capazes de formar apenas alguns tecidos, não todos. ${ }^{(32)}$

Sobre o tema, o cientista Steven Rehen, que participou da audiência pública, explicou:

Como foi comentado pelos colegas, existem dois tipos de células-tronco, são as células-tronco embrionárias, chamadas de pluripotentes, derivadas de embriões com 5 a 7 dias in vitro e que são capazes de gerar todas as células do corpo. $O$ segundo tipo dão as células-tronco adultas, que são as multipotentes, que são capazes de se diferenciar em tipos restritos e derivados de vários tecidos: medula óssea, fígado, polpa de dente e cordão umbilical. (...) Em relação ao potencial de diferenciação, as adultas têm um potencial restrito, enquanto as embrionárias têm um potencial irrestrito por poderem se transformar em todos os tecidos do corpo (...)..(33)

Em seu voto, o ministro relator explicitou que não há inconstitucionalidade no fato de a Lei de Biossegurança acolher a tese científica de que "as células-tronco embrionárias são dotadas de maior versatilidade para, orientadamente, em laboratório, 'se converterem em qualquer dos 216 tipos de célula do corpo humano"'.(34)

Nesse mesmo sentido, importa ressaltar parte do voto da ministra Carmen Lúcia:

As células-tronco embrionárias, imaturas, primitivas, e pluri ou totepotentes, produzidas em laboratórios, é que são, portanto, objeto do dispositivo legal posto em questão. Essas células são consideradas - no atual estágio da pesquisa científica, potencialmente aptas a gerar quaisquer tecidos do organismo humano, permitindo a renovação das células linfoides e mieloides e, assim, a produção de células diferenciadas no tecido sanguíneo.

É essa aptidão potencial das células-tronco embrionárias, não repetida nas células-tronco adultas, havidas no organismo desenvolvido, que distingue e valoriza as primeiras e torna-as especialmente atrativas para a pesquisa a partir da qual possam surgir novos tratamentos disponibilizados para o bem e a dignidade do ser humano.

Podendo tornar-se diferentes tecidos do organismo são elas que podem conduzir a novos patamares de pesquisa em benefício de todas as pessoas, em especial das que padeçam de doenças degenerativas (mal de Alzheimer, mal de Parkinson, esclerose múltipla, diabetes, distúrbios cardiovasculares, dentre outras).(35)

O argumento da importância das pesquisas com células-tronco embrionárias é embasado em resultados de sucesso. Conforme anteriormente mencionado, várias pesquisas realizadas com animais comprovam a alta capacidade de diferenciação das células-tronco embrionárias. No laboratório da Universidade Federal do Rio de Janeiro, por exemplo, foram realizadas pesquisas que

(32) AUDIÊNCIA Pública Células-Tronco. TV Justiça, Brasília-DF, 20 abr. 2007, cit.

(33) Id. Ibid.

(34) $\mathrm{ADI} \mathrm{n}^{\circ}$ 3.510-0.

(35) Id. Ibid. 
demonstram a capacidade das células embrionárias de se transformarem em neurônios, em função de determinados estímulos. Tais pesquisas mostraram, também, ser possível implantar essas células no cérebro para compor a rede neural. ${ }^{(36)}$

Além disso, na audiência pública, a pesquisadora Rosália Mendez-Otero citou a existência de estudos com células-tronco embrionárias realizados na Suécia que conseguiram determinar a cura para pacientes portadores do mal de Parkinson ${ }^{(37)}$. Também foram explicitados resultados positivos da pesquisa com células embrionárias no tratamento e controle da neoplasia. ${ }^{(38)}$

\section{CONSIDERAÇÕES FINAIS}

O caso da $A D I n^{\circ} 3.510-0$ demonstrou que as audiências públicas realizadas no âmbito do Poder Judiciário podem constituir um fórum eficiente para a realização da advocacia em saúde. A participação em audiências promovidas perante o Superior Tribunal Federal possui importante repercussão, em razão do caráter vinculante geral (efeito erga omnes) que as decisões emanadas desse órgão possuem.

Especificamente, o caso das células-tronco embrionárias representou um sucesso de advocacia em saúde. A participação na audiência pública por parte de especialistas engajados em pesquisas com a referida espécie celular influenciou diretamente o convencimento dos ministros do Supremo Tribunal Federal. Essa influência pôde ser comprovada pela fundamentação dos votos de um grupo de ministros com base em transcrições e citações expressas de trechos proferidos na audiência pública pelos especialistas defensores da Lei de Biossegurança. Dentre os seis ministros que decidiram pela improcedência da ADI $n^{\circ} 3.510$, três citaram expressamente vários trechos pronunciados pelos expositores favoráveis à pesquisa com células embrionárias, revelando a influência desses argumentos na formação do convencimento.

Acredita-se que o alcance da audiência pública sobre o convencimento dos ministros do STF tenha ido além do que o presente trabalho foi capaz de apurar. Contudo, feita essa ressalva, é importante ter presente que a influência da advocacia em saúde, realizada na audiência pública da ADI n³.510-0, sobre o convencimento dos ministros só pode ser apurada com um mínimo grau de certeza, mediante a constatação de dados objetivos, tais como transcrições e menções expressas a nomes de participantes expositores.

Os argumentos aduzidos na audiência pública e acolhidos pelos ministros

(36) AUDIÊNCIA Pública Células-Tronco. TV Justiça, Brasília-DF, 20 abr. 2007, cit.

(37) Id. Ibid.

(38) Id. Ibid. 
que julgaram favoravelmente as pesquisas com células embrionárias, nos termos da Lei de Biossegurança, abrangeram as questões da inviabilidade dos embriões utilizados nas pesquisas, do aborto, da irrelevância de discussão sobre o início da vida, do grau de proteção do embrião pelo ordenamento jurídico e da importância da pesquisa com células-tronco embrionárias. Esses argumentos foram utilizados na fundamentação dos votos de metade dos ministros que votaram em prol da Lei de Biossegurança.

O julgamento pela improcedência da ADI n $3.510-0$, pelo STF, representou a ratificação de uma política pública de saúde por parte do Poder Judiciário. A advocacia em saúde é normalmente feita perante os Poderes Executivo e Legislativo. É verdade que, no caso da elaboração da Lei de Biossegurança, publicada em 2005, foi realizado intenso movimento de advocacia em saúde em prol de pesquisa com células-tronco embrionárias no âmbito do Congresso Nacional. No entanto, diante do papel cada vez mais relevante assumido pelo Supremo Tribunal Federal no controle de políticas públicas, influenciando a implementação de planos e programas concebidos pelos Poderes Executivo e Legislativo ${ }^{(39)}$, a advocacia em saúde assume grande utilidade também perante o Poder Judiciário.

A utilização de audiências públicas no âmbito do Poder Judiciário pode, portanto, ser bastante favorável à realização de advocacia em saúde, promovendo efeitos e repercussão tão significativos quanto a advocacia em saúde realizada na esfera dos Poderes Executivo e Legislativo, visando, no primeiro caso, garantir a eficácia do direito à saúde, garantido formalmente, no plano jurídico.

\section{REFERÊNCIAS}

AUDIÊNCIA Pública Células-Tronco. TV Justiça, Brasília-DF, 20 abr. 2007. Disponível em:<http://www.tvjustica.jus.br/videos/audiencia_DV0811_CELULAS_ TRONCO_P1.wmv>. Acesso em: 06 mar. 2012.

BELLEM, Rafael Scavone de Lima. A audiência pública realizada na ADI 3510: a organização e o aproveitamento da primeira audiência pública da história do Supremo Tribunal Federal. Monografia (Conclusão de Curso) - Sociedade Brasileira de Direito Público, SBDP, Escola de Formação, São Paulo, 2008.

CANEL, Regina Célia; CASTRO, Cláudio Gastão Junqueira de. A advocacia em saúde como uma estratégia para a promoção da saúde. Revista de Direito Sanitário, São Paulo, v. 9, n. 1, p. 74-85, mar./jun. 2008.

(39) A influência do Poder Judiciário sobre questões caras à sociedade brasileira tem aumentado vertiginosamente, por razões que não cumprem ser discutidas aqui, mas que culminam, dentre outras situações, na intensificação da judicialização de políticas públicas. 
DALLARI, Sueli Gandolfi et al. Advocacia em saúde no Brasil contemporâneo. Revista Saúde Pública, São Paulo, v. 30, n. 6, p. 592-601, 1996.

DELDUQUE, Maria Célia; BARDAL, Priscila Ariede Petinuci. Advocacia em saúde: prática cidadã para a garantia do direito à saúde - o caso do projeto de Lei Complementar n 01/2003. Revista de Direito Sanitário, São Paulo, v. 9, n. 1, p. 107-122, mar./jun. 2008.

FERRAZ JR., Tércio Sampaio, Introdução ao estudo do direito: técnica, decisão e dominação. 4. ed. São Paulo: Atlas, 2003.

MEDEIROS, Fabrício Juliano Mendes. O Supremo Tribunal Federal e a primeira audiência pública de sua história. Revista Jurídica, Brasília, v. 9, n. 84, p. 41-48, abr./maio 2007.

PEREIRA, Lygia da Veiga. A importância do uso das células-tronco para a saúde pública. Ciência \& Saúde Coletiva, Rio de Janeiro, v. 13, n. 1, p. 7-14, fev. 2008.

TORRONTEGUY, Marco Aurélio Antas; RAUPP, Luciane. Obstáculos políticos à advocacia sanitária no Brasil: a pesquisa com células-tronco embrionárias. Revista de Direito Sanitário, São Paulo, v.9, n.1, p. 86-106, mar/jun. 2008.

ZIONI, Fabíola. A advocacia em saúde e sua contribuição à democracia. Revista de Direito Sanitário. São Paulo, v. 9, n. 1, p. 70-73, maio/jun. 2008. 